\title{
Pengaruh Tepung Azolla microphylla Terfermentasi dalam Pakan terhadap Penggunaan Protein pada Ayam Kampung Persilangan
}

\section{The Effect of Azolla microphylla Fermented Powder in the Diet to use Protein of Crossbreed Native Chicken}

\author{
S. N. Melita*, R. Muryani dan I. Mangisah \\ Fakultas Peternakan dan Pertanian, Universitas Diponegoro, Semarang, 50275 \\ *E-mail: sarifanurmelita@gmail.com
}

(Diterima: 17 Oktober 2017; Disetujui: 20 Desember 2017)

\begin{abstract}
ABSTRAK
Penelitian bertujuan untuk mengkaji pengaruh fermentasi tepung Azolla microphylla dalam pakan terhadap penggunaan protein ayam kampung persilangan. Materi penelitian adalah 80 ekor anak ayam kampung persilangan (ayam kampung dan ayam ras tipe petelur) umur 5 minggu dengan bobot rata-rata $469,80 \pm 38$ g $(\mathrm{CV}=3,33 \%)$. Penelitian menggunakan Rancangan Acak Lengkap (RAL) yang terdiri dari 4 perlakuan dengan 4 ulangan dan tiap ulangan terdiri dari 5 ekor. Perlakuan yang diuji sebagai berikut: T0 (Pakan tanpa tepung Azolla microphylla terfermentasi), T1 (Pakan dengan 10\% tepung Azolla microphylla terfermentsi), T2 (Pakan dengan 15\% tepung Azolla microphylla terfermentasi), T3 (Pakan dengan 20\% tepung Azolla microphylla terfermentasi). Parameter yang diukur adalah konsumsi protein, kecernaan protein kasar, retensi nitrogen dan bobot badan. Data yang diperoleh diolah dengan ANOVA dan dilanjutkan dengan Uji Duncan taraf 5\%. Hasil penelitian menunjukan penggunaan tepung Azolla microphylla terfermentasi berpengaruh nyata $(\mathrm{P}<0,05)$ terhadap konsumsi protein dan bobot badan, namun tidak diperoleh pengaruh nyata $(\mathrm{P}>0,05)$ terhadap kecernaan protein kasar dan retensi nitrogen. Kesimpulan dari penelitian ini adalah tepung Azolla microphylla hingga level 20\% dapat menurunkan konsumsi protein dan bobot badan akan tetapi dapat memberikan kecernaan protein dan retensi nitrogen yang sama.
\end{abstract}

Kata kunci: ayam kampung persilangan, fermentasi, protein, tepung Azolla microphylla

\section{ABSTRACT}

The research was aimed to evaluate the effect of Azolla microphylla fermented powder in the diet to use protein of crossbreed native chicken (male native chicken $x$ female laying hen). The research material was 80 chicks crossbreed native chicken age of 4 weeks with an average body weight of $469.80 \pm 38 \mathrm{~g}$ (CV $=3.33 \%$ ). Research used Completely Randomized Design (CRD) with be composed of 4 treatments with 4 replications and each replication consisting of 5 tails. The feeding treatments were: T0 (diet without fermented Azolla microphylla flour), T1 (diet with 10\% fermented Azolla microphylla flour), T2 (diet with 15\% fermented Azolla microphylla flour), T3 (diet with 20\% fermented Azolla microphylla flour). Parameters measured were protein consumption, crude protein digestibility, nitrogen retention. The data were analyzed using ANOVA and continued by Duncan's multiple range test. The result showed that the use of fermented Azolla microphylla flour was significantly effected $(P<0.05)$ on protein consumption, but not a significant effect on crude protein digestibility and nitrogen retention. The conclusion of this study is Azolla microphylla fermented powder to level $20 \%$ can reduce protein consumption and body weight but can give the same protein digestion and nitrogen retention.

Keywords: Azolla microphylla powder, crossbreed native chicken, fermentation, protein

\section{PENDAHULUAN}

Persilangan antara ayam kampung dengan ayam ras merupakan upaya untuk mengatasi kendala yang dihadapi dalam pemeliharaan ayam kampung yaitu pertumbuhan ayam yang lambat sehingga biaya produksi yang dibutuhkan relatif mahal. 
Biaya pakan untuk ayam kampung persilangan menyumbangkan $60-70 \%$ dari biaya produksi. Bahan pakan yang mengandung protein tinggi memiliki harga yang relatif mahal dibandingkan yang lainnya, sehingga dibutuhkan bahan alternatif salah satunya adalah Azolla microphylla. Penggunaan Azolla microphylla untuk peternak lokal sekitar perairan sangat potensial sebagai bahan pakan sumber protein

Azolla microphylla merupakan tumbuhan air yang memiliki daun kecil bertumpuk bewarna hijau dan dapat dibudidayakan di kolam dengan ukuran sesuai yang dibutuhkan. Azolla microphylla memiliki keunggulan sebagai bahan pakan untuk unggas yaitu kandungan proteinnya yang tinggi sebesar $20-35 \%$, selain itu terdapat keunggulan lainnya seperti vitamin A dan B12 serta asam amino esensial seperti lisin (kandungan lisin sebesar 0,42\%). Penggunaan Azolla microphylla hingga level $9 \%$ dalam pakan menghasilkan bobot kuning telur, indeks haugh, indeks putih telur dan indeks kuning telur yang sama pada telur ayam arab. Akan tetapi, penggunaan Azolla microphylla pada level 6\% dalam pakan ayam arab dapat meningkatkan bobot telur, bobot putih telur dan warna kuning telur (Argo et al., 2013). Disisi lain, Azolla microphylla sebagai bahan pakan unggas yaitu kandungan serat kasar yang tinggi sekitar 23,16\% dengan kandungan lignin $<15 \%$ dan selulosa berkisar $14,08 \%$ (Noferdiman, 2014). Serat kasar dapat menurunkan kecernaan nutrient, salah satunya protein. Kecernaan protein yang rendah dapat menyebabkan rendahnya ketersediaan asam-asam amino yang dibutuhkan untuk pembentukan daging. Oleh karena itu, perlu dilakukan suatu pengolahan salah satunya dengan fermentasi. Fermentasi dengan bantuan mikroorganisme tertentu diharapkan dapat menurunkan kandungan serat kasar, memperbaiki kualitas gizi dan meningkatkan kecernaan sehingga pemanfaatan nutrient menjadi optimal. Fermentasi tepung Azolla microphylla membutuhkan starter, diantaranya EM-4.
EM-4 dapat sebagai starter memiliki keunggulan karena terdapat mikroorganisme menguntungkan didalamnya. Kekurangan dalam penggunaan EM-4 yaitu mikroorganisme yang beragam didalam EM-4 menyebabkan $\mathrm{pH}$ untuk menumbuhkan berbeda dan waktu fermentasi bervariasi sesuai dengan spesies dan kondisi pertumbuhannya (Tifani et al., 2013). Fermentasi tepung Azolla microphylla dengan EM-4 diharapkan dapat memperbaiki kualitas serat kasar, protein dan nutrient lain sehingga dapat meningkatkan kecernaan. Peningkatan kecernaan protein dapat meningkatkan retensi nitrogen yang akan digunakan untuk proses pembentukan daging dan meningkatkan bobot badan ayam kampung persilangan.

Tujuan dari penelitian ini adalah mengkaji level penggunaan tepung Azolla microphylla yang difermentasi EM-4 dilihat dari aspek penggunaan protein pada ayam kampung persilangan.

\section{METODE}

Penelitian dilaksanakan pada bulan 19 Desember 2016-26 Februari 2017 di Fakultas Peternakan dan Pertanian, Universitas Diponegoro, Semarang, Indonesia.

Materi yang digunakan yaitu 80 ekor anak ayam kampung persilangan umur 5 minggu dengan bobot rata-rata 469,80 $\pm 38 \mathrm{~g}$ $(\mathrm{CV}=3,33 \%)$. Bahan pakan untuk menyusun ransum adalah jagung, bekatul, tepung ikan, bungkil kedelai, pollard, premix, $\mathrm{CaCO}_{3}$ dan tepung Azolla microphylla terfermentasi. Komposisi bahan dan kandungan nutrisi pakan disajikan pada (Tabel 1).

Rancangan percobaan yang digunakan adalah Rancangan Acak Lengkap (RAL) dengan 4 perlakuan dan 5 ulangan, setiap unit percobaan terdiri atas 5 ekor. Perlakuan yang diberikan adalah T0: Pakan tanpa tepung Azolla microphylla terfermentasi; T1: Pakan dengan $10 \%$ tepung Azolla microphylla terfermentsi; T2: Pakan dengan 15\% tepung Azolla microphylla terfermentasi; T3: Pakan 
Tabel 1. Komposisi Pakan Penelitian dan Kandungan Nutrisi.

\begin{tabular}{|c|c|c|c|c|}
\hline \multirow{2}{*}{ Bahan Pakan } & \multicolumn{4}{|c|}{ Pakan Perlakuan } \\
\hline & $\mathrm{T} 0$ & T1 & $\mathrm{T} 2$ & $\mathrm{~T} 3$ \\
\hline Jagung (\%) & 55 & 54,4 & 54,6 & 54,7 \\
\hline Bekatul (\%) & 15,3 & 12,5 & 12 & 9,1 \\
\hline Tepung Ikan (\%) & 5 & 3,5 & 3,5 & 3,5 \\
\hline Pollard (\%) & 11 & 7,7 & 4 & 3 \\
\hline Bungkil Kedelai (\%) & 12 & 10,2 & 9,2 & 8 \\
\hline $\mathrm{CaCO}_{3}$ & 0,7 & 0,7 & 0,7 & 0,7 \\
\hline Premix & 1 & 1 & 1 & 1 \\
\hline Tepung Azolla microphylla & 0 & 10 & 15 & 20 \\
\hline Total $(\%)$ & 100 & 100 & 100 & 100 \\
\hline \multicolumn{5}{|l|}{ Kandungan Nutrien } \\
\hline Protein kasar $(\%)^{1)}$ & 17,24 & 17,35 & 17,53 & 17,68 \\
\hline $\mathrm{EM}(\mathrm{kkal} / \mathrm{kg})^{1)}$ & 2709,97 & 2923,63 & 3028,82 & 3129,05 \\
\hline Serat kasar $(\%)^{1)}$ & 5,00 & 6,62 & 7,54 & 8,11 \\
\hline 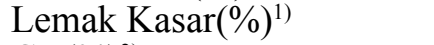 & 4,94 & 4,79 & 4,85 & 4,68 \\
\hline $\mathrm{Ca}(\%)^{2)}$ & 0,66 & 0,72 & 0,80 & 0,87 \\
\hline $\mathrm{P}(\%)^{2)}$ & 0,75 & 0,66 & 0,63 & 0,60 \\
\hline $\operatorname{Lisin}(\%)^{2)}$ & 0,80 & 0,86 & 0,91 & 0,97 \\
\hline Metionin $(\%)^{2)}$ & 0,27 & 0,33 & 0,37 & 0,40 \\
\hline
\end{tabular}

Sumber: ${ }^{1)}$ Hasil Analisis proksimat Laboratorium Ilmu Nutrisi Ternak dan Pakan Universitas Diponegoro, Semarang (2017).

2) Hartadi et al. (1980).

dengan 20\% tepung Azolla microphylla terfermentasi.

Cara pembuatan Tepung Azolla microphylla fermentasi yaitu menggunakan EM-4 yaitu Azolla microphylla sebanyak 4500 g ditambahkan air (ml) dan EM4 (ml) dengan perbandingan $15: 1500$ kemudian dilakukan pemeraman selama 7 hari untuk memperoleh kerja mikroorganisme yang optimal.

Konsumsi protein dilakukan dengan cara menimbang pemberian dan sisa pakan setiap hari selama penelitian (42 hari), Pengambilan data kecernaan protein kasar dan retensi nitrogen (umur 9 minggu) dilakukan dengan metode total koleksi menggunakan $\mathrm{HCl} 0,2 \mathrm{~N}$. Data yang diperoleh dilakukan uji analisis kadar air dan kadar protein kasar di Laboratorium Laboratorium Ekologi dan Produksi Tanaman Fakultas Peternakan dan Pertanian, Universitas Diponergoro.

Parameter yang diukur diantaranya konsumsi protein, kecernaan protein kasar, retensi nitrogen dan bobot badan.
1. Konsumsi protein

Konsumsi protein dapat dihitung dengan rumus menurut Tillman et al. (1998) sebagai berikut:

Konsumsi Protein $(\mathrm{g})=$ Konsumsi pakan $(\mathrm{g})$ x PK pakan (\%)

Keterangan:

Konsumsi pakan $=$ pakan terkonsumsi - sisa pakan.

\section{Kecernaan Protein Kasar}

Kecernaan protein kasar dapat dihitung dengan rumus menurut Fitasari et al. (2011) sebagai berikut:

$\operatorname{KcPK}(\%)=$

Konsumsi PK - J.Protein ekskreta kansumsi Protein Kasar $\mathrm{x} 100 \%$

Keterangan:

$\mathrm{KcPK}=$ Kecernaan Protein Kasar

Konsumsi PK $=$ Jumlah konsumsi pakan $\mathrm{x}$ \%Protein kasar pakan

J. Protein ekskreta $=$ J. ekskreta dalam $100 \%$ BK $x$ Kadar Protein Ekskreta 


\section{Retensi Nitrogen}

Retensi Nitrogen dapat dihitung dengan rumus menurut Wolynetz dan Sibbald (1984) sebagai berikut:

$\mathrm{RN}(\mathrm{g})=\underset{\text { endogenous })}{\mathrm{N} \text { konsumsi }}-(\mathrm{N}$ ekskresi-N

Keterangan:

$\mathrm{N}$ konsumsi $(\mathrm{g}) \quad=$ konsumsi pakan $\mathrm{x} \%$ nitrogen pakan

N ekskresi $(\mathrm{g})=$ Bobot ekskreta $\mathrm{x} \%$ nitrogen ekskreta

$\mathrm{N}$ Endogenous $(\mathrm{g})=$ Bobot ekskreta $\mathrm{x} \%$ nitrogen endogenous

4. Bobot Badan

Bobot diketahui dengan cara melakukan penimbangan ayam pada akhir penelitian (umur 10 minggu).

\section{HASIL DAN PEMBAHASAN}

Hasil penelitian mengenai pengaruh tepung Azolla microphylla terfermentasi terhadap konsumsi protein, kecernaan protein kasar, retensi nitrogen dan bobot badan ayam kampung persilangan disajikan pada Tabel 2 .

\section{Konsumsi Protein}

Hasil analisis ragam menunjukan pengaruh tepung Azolla microphylla terfermentasi berbeda nyata $(\mathrm{P}<0,05)$ terhadap konsumsi protein. Rata-rata konsumsi protein dapat dilihat pada (Tabel 2). Konsumsi protein pada ayam kampung persilangan yang diperoleh lebih tinggi dibandingkan dengan penelitian Trisiwi (2016) menunjukkan bahwa pengurangan level protein hingga $16 \%$ dengan mengganti sebagian pakan starter broiler dengan tepung roti pada ayam kampung persilangan yang dipelihara selama 56 hari memperoleh hasil konsumsi protein berkisar 4,46-7,45 g/ekor/hari. Ayam akan mengkonsumsi pakan lebih banyak apabila kapasitas di dalam tembolok belum terpenuhi walaupun kandungan energi pakan tinggi. Tembolok merupakan pusat rangsangan kenyang dan lapar. Menurut Zulfanita et al. (2011), unggas akan mengkonsumsi pakan melebihi kuantitas yang diperlukan walaupun energi sudah terpenuhi dikarenakan kapasitas tembolok belum mencapai rasa kenyang.

Azolla microphylla sebagai tumbuhan air memiliki kandungan serat kasar dan zat anti nutrisi berupa tanin. Tanaman Azolla memiliki kandungan tanin sekitar 1,00 $3,46 \%$, sedangkan kandungan tanin yang dapat ditoleransi ayam hanya sekitar $0,5-1 \%$. Menurut Setiarto dan Widhyastuti (2016), Sacchoromyces cerevisiae, yang merupakan bagian dari mikroorganisme di dalam EM4, dapat menghidrolisis tanin dengan menghasilkan enzim tanase ekstraseluler yang mampu menghidrolisis ikatan ester pada senyawa tanin menjadi glukosa dan asam galat. Fermentasi dapat meningkatkan kandungan energi metabolis pada tepung Azolla microphylla. Level penggunaan hingga $20 \%$ mempengaruhi kandungan energi metabolis pakan yang semakin meningkat. Menurut Sari et al. (2014), ayam akan mengkonsumsi pakan lebih banyak apabila kandungan energinya rendah begitu pula sebaliknya, ayam akan mengurangi pakan yang dikonsumsi apabila energinya tinggi. Namun demikian, kandungan energi metabolis pada T0 lebih rendah dibandingkan dengan T1, T2 dan T3 akan tetapi hal tersebut tidak dapat meningkatkan konsumsi protein pada T0. Disisi lain, yang menyebabkan rendahnya konsumsi protein adalah asam amino metionin pada perlakuan T0 $(0,27 \%)$ dibawah kebutuhan asam amino pada ayam kampung persilangan yaitu sekitar 0,30\%. Konsumsi protein berkaitan dengan konsumsi pakan. Samadi (2012) menyatakan bahwa salah satu asam amino yang kurang memenuhi kebutuhan menyebabkan terhambatnya asam amino yang lain walaupun asam amino tersebut cukup tersedia dalam pakan.

\section{Kecernaan Protein Kasar}

Hasil analisis ragam menunjukan bahwa tepung Azolla microphylla terfermentasi tidak memberikan pengaruh yang nyata $(\mathrm{P}>0,05)$ terhadap kecernaan protein kasar (Tabel 2). Menurut Situmorang et al. (2013), kecernaan protein kasar pakan yang normal untuk ayam yaitu 75 hingga $90 \%$ atau rata-rata 
Vol. 20 (1): 8-14

Tabel 2. Pengaruh Perlakuan terhadap Penggunaan Protein pada Ayam Kampung Persilangan

\begin{tabular}{lcccc}
\hline \multirow{2}{*}{ Parameter } & \multicolumn{4}{c}{ Perlakuan } \\
\cline { 2 - 5 } & $\mathrm{T} 0$ & $\mathrm{~T} 1$ & $\mathrm{~T} 2$ & $\mathrm{~T} 3$ \\
\hline Konsumsi Protein $(\mathrm{g})$ & $9,96^{\mathrm{b}}$ & $10,62^{\mathrm{a}}$ & $10,76^{\mathrm{a}}$ & $10,61^{\mathrm{a}}$ \\
KcPK (\%) & 73,92 & 71,91 & 72,44 & 81,22 \\
Retensi Nitrogen $(\mathrm{g})$ & 1,77 & 1,95 & 1,99 & 2,15 \\
Bobot Badan $(\mathrm{g})$ & $886,30^{\mathrm{c}}$ & $916,10^{\mathrm{ab}}$ & $943,00^{\mathrm{a}}$ & $889,15^{\mathrm{bc}}$ \\
\hline
\end{tabular}

Keterangan: Superskrip huruf kecil yang berbeda pada baris yang sama menunjukkan perbedaan nyata $(\mathrm{P}<0,05)$

$85 \%$. Faktor yang mempengaruhi persentase kecernaan protein kasar diantaranya sumber protein, kandungan protein dan konsumsi protein. Sukaryana et al. (2011) menyatakan bahwa kecernaan protein kasar dipengaruhi oleh beberapa faktor diantaranya jenis ternak, bentuk dan struktur bahan pakan, proporsi pakan, kandungan lignin bahan pakan, gangguan pada saluran pencernaan dan kandungan zat antinutrisi.

Kecernaan protein kasar yang diperoleh pada level $10 \%$ hingga $20 \%$ adalah sama karena adanya proses fermentasi. Fermentasi menyababkan tepung Azolla microphylla mudah untuk dicerna. Menurut Sukaryana (2007) penguraian komponen protein kasar yang mudah dicerna merupakan cerminan dari fermentasi. Rizkianingtyas et al. (2016) menyatakan bahwa tinggi rendahnya nilai kecernaan tergantung pada kandungan protein bahan pakan dan banyaknya protein yang terserap dan tercerna di dalam saluran pencernaan.

\section{Retensi Nitrogen}

Rata-rata retensi nitrogen pakan perlakuan T0, T1, T2 dan T3 yaitu 1,34 g; 1,66 g; 1,79 g; dan 1,83 g. Menurut Ma'rifah et al. (2013), retensi nitrogen pada ayam kampung persilangan yang diberi kayambang (Salvina molesta) hingga taraf $18 \%$ berkisar 1,11 hingga 2,06 g, kayambang merupakan tumbuhan air memiliki serat kasar yang tinggi sama seperti halnya dengan Azolla microphylla. Fransisca et al. (2017) menyatakan bahwa retensi nitrogen adalah suatu metode untuk mengetahui jumlah nitrogen yang diserap oleh tubuh dengan cara mengukur nitrogen yang dikonsumsi dan nitrogen yang dikeluarkan berupa feses dan urin.

Tepung A. microphylla terfermentasi dalam pakan tidak berpengaruh nyata $(\mathrm{P}>0,05)$ terhadap retensi nitrogen ayam kampung persilangan. Menurut Hidayati dan Sujono (2006), retensi nitrogen dipengaruhi oleh beberapa faktor yaitu kandungan protein dalam pakan, konsumsi pakan, dan proses metabolisme tubuh. Metabolisme protein di dalam tubuh membutuhkan kecukupan energi metabolis untuk memperoleh pertambahan bobot badan yang optimal. Nugrahadi et al. (2016) menyatakan bahwa nitrogen yang tertahan di dalam tubuh akan dideposisi dan disintesis menjadi protein dan asam-asam amino yang membentuk daging.

\section{Bobot Badan}

Rata-rata bobot badan dapat dilihat pada (Tabel 2). Bobot badan yang diperoleh pada ayam kampung persilangan selama 6 minggu sudah sesuai dengan hasil penelitian sebelumnya. Beberapa penelitian (Winaya et al., 2010; Basak, 2002; Frasiska et al., 2013) yang menggunakan tepung Azolla microphylla dengan berbagai level menyimpulkan bahwa penggunaan tepung Azolla microphylla pada ayam broiler dan itik peking menghasilkan bobot badan yang optimal dan tidak mengganggu metabolisme tubuh. Trisiwi et al. (2016) menyatakan bahwa ayam kampung persilangan yang dipelihara selama 10-12 minggu dapat mencapai bobot berkisar $900 \mathrm{~g}$ hingga $1500 \mathrm{~g}$.

Perlakuan tepung Azolla microphylla terfermentasi dalam pakan berpengaruh nyata $(\mathrm{P}<0,05)$ terhadap bobot badan pada ayam kampung persilangan. Hal ini diduga oleh keseimbangan asam amino esensial 
dalam pakan dapat mendukung pertumbuhan pada ayam kampung persilangan. Tepung Azolla microphylla terfermentasi memiliki kandungan asam amino lisin yang dapat mendukung pertumbuhannya. Menurut Maryuni dan Wibowo (2005), lisin merupakan asam amino essensial yang kritis untuk ayam untuk memenuhi kebutuhan pertumbuhan ayam sehingga diperoleh pertumbuhan yang cepat dan optimal. Keseimbangan asam amino akan mendukung pertambahan bobot badan pada ayam sehingga akan mencapai bobot badan yang optimal. Anggrodi (1995) menyatakan bahwa lisin merupakan asam amino yang antagonis terhadap arginin, ketidakseimbangan asam amino membutuhkan energi yang relatif tinggi sehingga menyebabkan pertumbuhan tidak maksimal.

\section{KESIMPULAN}

Berdasarkan penelitian, tepung Azolla microphylla terfermentasi hingga level 20\% tidak meningkatkan kecernaan protein kasar dan retensi nitrogen, namun konsumsi protein dan bobot badan level terbaik penggunaan tepung Azolla microphylla terfermentasi adalah $10 \%$.

\section{DAFTAR PUSTAKA}

Anggrodi, R. 1995. Nutrisi Aneka Ternak Unggas. Gramedia Pustaka Utama, Jakarta.

Basak, B., Pramanik, A.H dam M.S. Rahman. 2002. Azolla (Azolla pinnata) as a feed ingredient in Broiler ration. Int. J. of Poult. Sci. 1 (1): 29-34.

Fitasari, E., K. Reo dan N. Niswi. 2011. Penggunaan kadar protein berbeda pada ayam kampung terhadap penampilang produksi dan kecernaan protein. J. Ilmu-ilmu Peternakan. 26 (2):73-83.

Hartadi, H., L.C. Kearl, S. Reksohadiprodjo, L.E. Harris dan S. Lebdosukojo. 1980. Tabel-tabel dari Komposisi Bahan Makanan Ternak untuk Indonesia. Data
Ilmu Makanan Untuk Indonesia. Logan, Utah: The International Feedstuff Institute Utah Agricultural Experiment Station, Utah State University.

Hidayati, A. dan Sujono. 2006. Pengaruh penggunaan tepung buah Mengkudu (Morinda citrifolia) terhadap pertambahan bobot badan dan tampilan pakan pada ayam pedaging. J. Protein. 13 (1): 10-16.

Mahfudz, L.D., U. Atmomarsono, D. Sunarti, E. Supijatna and T.A. Sarjana. 2011. Protein consumption and efficiency of Kedu, arab and their crossing chickens feed diets with different protein levels. Egypt. Poult. Scie. 31 (2): 491-500.

Maryuni, S.S. dan C.H. Wibowo. 2005. Pengaruh kandungan lisin dan energi metabolis dalam ransum yang mengandung Ubi Kayu fermentasi terhadap konsumsi ransum dan lemak ayam Broiler. J. Indon. Trop. Anim. Agric. 30 (1): 26-33.

Noferdiman., H. Syafwan dan Sestilawarti. 2014. Dosis inokulan lama fermentasi jamur Pleurotus ostreatus terhadap kandungan nutrisi Azolla microphylla. J. Peternakan. 11 (1): 29-36.

Nugrahadi, P.D., N. Suthama dan I. Mangisah. 2016. Massa protein daging Itik jantan yang diberi pakan tepung kulit bawng merah dan bawang putih. Dalam: Sugiharto., Surono, Sutaryo dan Karyanto (Ed). Prosiding Seminar Nasional Kebangkitan Peternakan II. Indonesian Society of Animal Agriculture. Semarang, 12 Mei 2016. Hal: 217-225.

Rizkianingtyas, R., L.D. Mahfudz dan B. Sukamto. 2016. Penggunaan tepung daun Mengkudu fermentasi dalam pakan terhadap laju digesta, kecernaan protein dan energi metabolis ayam Kampung Super. Dalam: Sugiharto., Surono, Sutaryo dan Karyanto (Ed). Prosiding Seminar Nasional Kebangkitan Peternakan II. Indonesian 
Society of Animal Agriculture. Semarang, 12 Mei 2016. Hal: 236-244.

Samadi. 2012. Konsep ideal protein (asam amino) focus pada ternak ayam pedaging. J. Agripet. 12 (2): 42-48.

Sari, M.L., Lubis, F.N.L dan L.D. Jaya. 2014. Pengaruh pemberian asap cair melalui air minum terhadap kualitas karkas ayam Broiler. Agripet. 14 (1):71-75.

Setiarto, R.H.B. dan N. Widhyastuti. 2016. Penurunan kadar tanin dan asam fitat pada tepung sorgum melalui fermentasi Rhizopus oligosporus, Lactobacillus plantarum dan Saccharomyces cerevisiae. Berita Biologi. 15 (2): 149157.

Situmorang, N.A., L.D. Mahfudz dan U. Atmomarsono. 2013. Pengaruh pemberian tepung Rumput Laut (Gracilaria verrucosa) dalam ransum terhadap efisiensi penggunaan protein ayam Broiler. Anim. Agric. J. 2 (2): 4956.

Sukaryana, Y. 2007. Optimalisasi pemanfaatan BIS, Gaplek dan Onggok melalui Teknologi Fermentasi dengan Kapang yang Berbeda sebagai Bahan Pakan Ternak Unggas. Laporan Penelitian Hibah Bersaing.

Sukaryana, Y., U. Atmomarsono. V.D. Yunianto dan E. Supriyatna. 2011. Peningkatan nilai kecernaan protein kasar dan lemak kasar produk fermentasi campuran bungkil inti sawit dan dedak pada pada Broiler. JITP 1 (30): 167-172.

Tifani, Tifani, M.A., Kumalaningsih, S dan A. F. Mulyadi. 2013. Produksi pakan ternak dari ampas tahu dengan fermentasi menggunakan EM4 (kajian $\mathrm{pH}$ awal dan lama waktu fermentasi). J. Penelitian. 1 (2): 35-36.

Tillman, A.D., Hartadi, H, Reksohadiprodjo, S, Prawiro K. S dan Lebdosoekoekojo. 1998. Ilmu Makanan Ternak Dasar. Gadjah Mada University Press, Yogyakarta.

Trisiwi, H.F. 2016. Pengaruh level protein pakan yang berbeda pada masa starter terhadap penampilan Ayam Kampung Super. J. Ilmiah Peternakan Terpadu. 4 (3): 256-262.

Winaya, A., Maftuchah dan A. Zainudin. 2010. Tanaman air Azolla sp. sebagai imbuhan pakan dan pengaruhnya terhadap tampilan produksi ayam Broiler strain Hubbard. Jurnal Sains Peternakan Indonesia. 5 (1): 1-12.

Wolynetz, M.S. and I.R. Sibbald. 1984. Relationship between apparent and true metabolizable energy and the effect of a nitrogen correction. Poultry Sci 63: 1386-1399. 